\title{
ANALISA KAPASITAS OUTRUNNER MOTOR BLDC SEBAGAI PENGGERAK MINI WATER PUMP DENGAN BATERAI 12 VOLT DARI SUMBER ENERGI MATAHARI
}

\section{Sariman, Niko Andrean}

Universitas Sriwijaya (UNSRI) Palembang Sumatera, Indonesia

Email: sariman78@yahoo.com niko.ndrean99@gmail.com

\begin{tabular}{l}
\hline INFO ARTIKEL \\
\hline Diterima \\
5 Juni 2021 \\
Direvisi \\
10 Juni 2021 \\
Disetujui \\
21 Juni 2021 \\
\hline
\end{tabular}

Keywords :

BLDC motors, water pump, water discharge, solar panels, battery

\begin{abstract}
The role of electric motors is important for human life such as industrial and home fields, namely 3-phase motors, AC and DC motors and BLDC motors. This study aims to determine the capacity of 2 BLDC motors with different sizes, namely $27 \times 27 \mathrm{~mm}$ and $35 \times 36 \mathrm{~mm}$ with RPM $1400 \mathrm{Kv}$ as a mini water pump driver. The study was conducted for 14 days and calculated on average. Charging electric current from the solar panel to the 0.313 A battery with a charging time of 22.9 hours so that the battery is fully charged. Weather factors and the level of light intensity affect the acquisition of electric current from solar panels. The highest efficiency is obtained on a BLDC Motor with a size of $35 \times 36 \mathrm{~mm}$, which is $86.79 \%$ under load conditions and for $87.75 \%$ in no-load conditions and water discharge is $0.59688 \mathrm{~L} / \mathrm{s}$, the power consumption of the battery is 238.2195 Watts and the duration of battery usage. 7,585 minutes under load condition. For a BLDC Motor measuring $27 \times 27$ $\mathrm{mm}$, the efficiency is $81.69 \%$ under load conditions and for $86.51 \%$ in no-load conditions and the water discharge is $0.55992 \mathrm{~L} / \mathrm{s}$, the power consumption of the battery is 217.9702 Watts and the battery usage time is 9.324 minutes. load condition. The decrease in the efficiency of the BLDC Motor is due to losses in the motor and friction losses in the pipe and the larger the motor size will be proportional to the value of the power required and the resulting water discharge.
\end{abstract}

How to cite:

E-ISSN:

Published by:
Sariman, Niko Andrean dkk (2021) Analisa Kapasitas Outrunner Motor BLDC Sebagai Penggerak Mini Water Pump dengan Baterai 12 Volt Dari Sumber Energi Matahari Jurnal Syntax Admiration 2(6). https://doi.org/10.46799/jsa.v2i6.259 $2722-5356$

Ridwan Institute 


\section{Kata Kunci:}

motor $B L D C$, pompa air, debit air, panel surya, baterai dengan RPM $1400 \mathrm{Kv}$ sebagai penggerak pompa air mini. Penelitian dilakukan selama 14 hari dan dihitung secara rata-rata. Pengisian arus listrik dari panel surya ke baterai 0,313 A dengan lama pengisian 22,9 jam agar baterai terisi penuh. Faktor cuaca serta tingkat intensitas cahaya berpengaruh dalam perolehan arus listrik dari panel surya. Efisiensi tertinggi didapat pada BLDC Motor ukuran 35 x $36 \mathrm{~mm}$ yaitu 86,79\% kondisi berbeban dan untuk $87,75 \%$ kondisi tanpa beban serta debit air dihasilkan 0,59688 L/s, konsumsi daya pada baterai 238,2195 Watt dan lama pemakaian baterai 7,585 menit kondisi berbeban. Untuk BLDC Motor ukuran 27 × 27 $\mathrm{mm}$ efisiensinya $81,69 \%$ kondisi berbeban dan untuk $86,51 \%$ kondisi tanpa beban serta debit air dihasilkan $0,55992 \mathrm{~L} / \mathrm{s}$, konsumsi daya pada baterai $217,9702 \mathrm{Watt}$ dan lama pemakaian baterai yaitu 9,324 menit kondisi berbeban. Penurunan efisiensi BLDC Motor disebabkan adanya rugi-rugi pada motor dan rugi gesekan pada pipa serta semakin besar ukuran motor akan sebanding dengan nilai daya yang dibutuhkan dan debit air yang dihasilkan.

\section{Pendahuluan}

Sebagai alat yang dibutuhkan dalam bidang Industri maupun rumahan yaitu motor listrik berperan penting dalam ruang lingkup kegiatan manusia. Contoh perananannya dalam bidang perindustrian yaitu motor induksi sebagai penggerak mesin produksi. Untuk skala rumahan seperti kipas angin, pompa air dan lainnya. Pada skala rumahan banyak dipakai Motor DC dalam penggunaannya, akan tetapi tingkat efisiensinya yang relatif rendah dikarenakan pada suatu sistem komutasinya masih menggunakan sikat atau brushed (Chandra Wibowo and Riyadi 2019). Dengan keadaan yang tingkat efisiensinya relatif kecil maka digunakanlah Motor BLDC (Brushless DC) yang merupakan motor sinkron magnet permanen dan memiliki suatu sistem elektrik pada komutasinya menggunakan kontroler. Pada Motor BLDC terdapat 3 lilitan yang terdapat di dalamnya dan dengan menggunakan sistem komutasi elektrik ketiga lilitan tersebut akan saling bergantian memiliki arus listrik positif dan negatif yang diatur oleh hall effect sensor, di mana pada sensor tersebut akan mengalirkan arus listrik dari positif ke negatif ketika bertemu dengan kutub selatan dan akan mengindikasi bahwa arus listrik akan dialirkan. Kecepatan perpindahan posisi urutan arus listrik yang mengalir pada masing-masing lilitan berlangsung secara cepat (Akbar and Riyadi 2019). Perubahan lilitan yang mendapatkan arus tersebut akan mengakibatkan medan magnet yang terjadi pada stator dan rotor yang akan menggerakan rotor dikarenakan terjadinya gaya gerak listrik. Meskipun arus yang mengalir pada Motor BLDC tersebut seperti Motor DC tetapi arus yang mengalir pada sistem komutasi tersebut bersifat arus 3 fasa (Jatmiko et al. 2018). Misalnya dalam penggunaan water pump kebanyakan digunakan Motor DC (Direct Current) maupun AC (Alternating Current). Pada Motor DC / Brushed DC 
meskipun memiliki kontrol sederhana dan harga relatif murah dibandingkan $B L D C$ Motor. Karena komutatornya menjadikan efisiensi rendah dan kurang dapat diandalkan. Motor $B L D C$ memiliki keunggulan kinerja, seperti efisiensi tinggi, struktur yang handal dan sederhana, serta respon dinamis lebih cepat, kecepatan tinggi, besar torsi awal, dan kebisingan rendah (Joon et al. 2012). Penggunaan water pump kebanyakan masih menggunakan listrik $A C$ dengan keadaan di mana water pump banyak ditempatkan diluar ruangan. Karena itu dapat memanfaatkan energi matahari sebagai sumber energi listrik dan dengan desain dan kontrol yang tepat Motor BLDC dapat menggantikan peranan pada Motor DC tersebut. Pompa merupakan alat yang dapat memindahkan suatu cairan atau fluida dari satu sumber ke sumber yang lain dan di gerakan oleh mesin sebagai penggerakya (Ainurrohmah, Rivai, and Tasripan 2019). Terdapat 3 Impeller pada pompa air yaitu Impeller tertutup, terbuka dan semi tertutup. Di mana masingmasing memiliki fungsi yang berbeda tergantung dari keadaan dan situasi dari zat cairan yang akan dialirkan (Candra 2018). Panel surya adalah suatu alat yang didalamnya terdapat jenis semi konduktor yaitu silikon dan dilapisi suatu bahan kimia dan tingkat ketebalannya sekitar 0,3 mm dan berukuran sangat kecil (Julisman, Sara, and Siregar 2017). Jenis panel surya diantaranya Monokristalin tingkat efisiensinya mencapai $15 \%$, Polikristalin tingkat efisiensi 12\%, Amorphous tingkat efisiensi 4-6\%, dan Thin Film dengan efisiensinya 8,5 \% (Purwoto 2018). SCC (Solar Charger Controller) merupakan sebuah alat yang digunakan dalam pengaturan sistem tenaga surya untuk pengisian baterai dengan menggunakan komponen yang dapat mengatur keluar masuknya arus listrik menuju baterai dari panel surya (Suryaputra et al. 2019). Baterai adalah perangkat yang di dalamnya terdapat arus listrik dan dapat dialirkan ke tempat lain. Di dalam baterai terdapat suatu zat kimia yang dapat menghasilkan energi listrik. Pada baterai terdapat sebuah plat dan bahan elektrolit yang dapat digunakan dan dapat diisi kembali arus listrik ke dalamnya. Proses tersebut disebut juga reversible (berkebalikan), di mana pada proses tersebut baterai dapat mensuplai arus listrik dan dapat juga menerima arus listrik sebagai pengisian arus listrik yang akan disimpan pada zat kimia elektrolit tersebut (Udin, Kaloko, and Hardianto 2017). Motor BLDC itu sendiri yaitu suatu motor yang digerakan dengan arus 3 fasa dan disebut juga dengan PMSM (Permanent Magnet Synchronous Motor). Motor sinkron itu sendiri berarti putaran atau medan magnet yang dihasilkan akan sama dengan frekuensi yang dibangkitkan antara rotor dan stator. Perbedaan inrunner dan Outrunner Motor BLDC yaitu terletak pada kontruksinya dan perbedaannya terdapat pada torsi yang dihasilkan lebih tinggi pada Outrunner BLDC, untuk kekurangannya Outrunner BLDC karena rotor berada diluar maka gangguan yang dapat terjadi lebih besar dibandingkan dengan inrunner Motor BLDC (Kumar et al. 2015). Kontruksi Outrunner Motor BLDC terdiri dari stator, rotor dan sensor posisi (Hall Effect Sensor). Rotor merupakan bagian yang berputar pada suatu motor listrik, pada Motor BLDC di dalam rotor tersebut terdapat beberapa kutub dan yang dipakai pada umumnya 2-8 pasang magnet kutub utara dan selatan. Stator pada Motor BLDC tersusun dari lapisan baja dan dilaminasi pada setiap slotnya dan terdapat kumparan lilitan kawat sebagai aliran arus yang masuk untuk menghasilkan medan magnet 
tersebut (Widaningrum, Setiyono, and Riyadi 2017). Penempatan sensor posisi biasa terletak pada stator untuk menentukan urutan komutasi dalam mengalirkan arus listrik dari ketiga fasa tersebut. Di mana dalam penerimaan sinyal antara high (1) atau low (0), perlu adanya pengidentifikasian antara kutub selatan dan utara. Ketika bertemu kutub selatan maka sensor akan bernilai 1 dan akan mengalirkan arus listrik lalu akan memutuskan arus listrik ketika bertemu kutub utara. Dengan terjadinya perpindahan arus listrik dari setiap fasa yaitu antara arus positif dan negatif maka akan terjadi perputaran pada motor dan perpindahan arus tersebut terjadi sangat cepat dan singkat (Sutedjo et al. 2017). Prinsip kerja Motor BLDC terjadi akibat adanya ggl induksi, Terjadinya proses gaya gerak listrik yaitu ketika medan stator dialiri arus listrik yang mengakibatkan adanya gaya tarik menarik antara rotor dan stator dan akan mengakibatkan berputarnya rotor. Perputaran rotor tersebut diakibatkan adanya medan elektromagnetik yang terjadi karena kumparan lilitan terdapat aliran arus listrik di mana dalam aliran arus listrik tersebut hanya 2 fasa yang tersuplai arus positif dan negatif dan salah satunya menjadi arus netral atau nol (Antono 2012). Penulis membaca penelitian dari M. H. Krishna and S. Manmadharao dengan judul Grid Integrated Solar Irrigation System by Using BLDC Motor Pump Set untuk pemanfaatan panel surya sebagai suplai pompa air pada sistem irigasi pertanian (Krishna and Manmadharao 2018).

Tujuan dalam penelitian yang dilakukan yaitu untuk mengetahui kapasitas kedua Motor $B L D C$ seperti nilai daya serta efisiensinya antara keadaan berbeban dan tanpa beban. Perhitungan pengisian panel surya ke baterai dan pemakaian baterai dari Motor $B L D C$ serta mengetahui debit aliran air yang dihasilkan dari kedua motor tersebut sebagai penggerak Mini Water Pump.

\section{Metode Penelitian}

Metodologi yang digunakan untuk mendapatkan hasil dari penelitian yaitu pertama, studi literatur untuk mencari, mengumpulkan, membaca dan memilih literatur berupa jurnal, artikel dan buku-buku sebagai referensi yang berhubungan dengan teori dan metode yang digunakan. Kedua, konsultasi dan diskusi dengan dosen pembimbing dan meminta pendapat dengan kakak tingkat serta teman-teman tentang penelitian yang akan dilaksanakan. Ketiga, konstruksi alat yaitu melakukan perencanaan, perancangan, dan pemasangan alat penelitian. Keempat, pengumpulan data yang diperlukan berupa data tegangan dan arus dari masing-masing komponen serta debit aliran air yang dihasilkan dari Mini Water Pump. Dan terakhir pengolahan data yaitu melakukan analisa dan perhitungan dari daya dan efisiensi BLDC Motor serta debit air yang dihasilkan dengan data-data yang telah didapatkan. 


\section{Tabel 1}

Alat dan Bahan

\begin{tabular}{|c|c|c|}
\hline \multicolumn{3}{|c|}{ Alat dan Bahan } \\
\hline Alat dan Bahan & Keterangan & Fungsi \\
\hline$d x$ & $\begin{array}{l}\text { Motor BLDC DYS dan } \\
\text { A2212 } 1400 \mathrm{KV} \text { ukuran } \\
35 \times 36 \mathrm{~mm} \text { dan } 27 \mathrm{x} \\
27 \mathrm{~mm}\end{array}$ & $\begin{array}{c}\text { Sebagai Penggerak Mini } \\
\text { Water Pump }\end{array}$ \\
\hline & $\begin{array}{lrll}\text { Panel Surya } & 10 & \text { WP } \\
\text { Policrystalline } & & \end{array}$ & $\begin{array}{c}\text { Sebagai sumber energi } \\
\text { listrik ke baterai }\end{array}$ \\
\hline & Baterai VRLA 12 V 7,2 Ah & $\begin{array}{c}\text { Sebagai suplai energi listrik } \\
\text { ke Motor } B L D C\end{array}$ \\
\hline & Ember/Wadah air & Tempat menampung air \\
\hline & Desain Mini Water Pump & $\begin{array}{l}\text { Sebagai media keluar } \\
\text { masuk aliran air dimana } \\
\text { terdapat baling-baling / } \\
\text { impeller yang di kopel } \\
\text { dengan BLDC Motor }\end{array}$ \\
\hline & Multimeter & $\begin{array}{l}\text { Alat ukur tegangan dan } \\
\text { arus pada panel, baterai }\end{array}$ \\
\hline & Lux Meter & $\begin{array}{c}\text { Alat ukur intensitas cahaya } \\
\text { dari matahari }\end{array}$ \\
\hline & Tang Meter & $\begin{array}{c}\text { Alat pengukur tegangan } \\
\text { dan arus pada Motor } B L D C\end{array}$ \\
\hline & Servo Motor Tester & $\begin{array}{l}\text { Sebagai kontroler pengatur } \\
\text { tegangan dan kecepatan } \\
\text { pada motor } B L D C\end{array}$ \\
\hline & $\begin{array}{l}\text { Skywalker ESC (Electronic } \\
\text { Speed Control) Brushless } \\
\text { Motor }\end{array}$ & $\begin{array}{c}\text { untuk mengubah kecepatan } \\
\text { motor listrik, jalur dan juga } \\
\text { berfungsi sebagai rem } \\
\text { dinamis }\end{array}$ \\
\hline 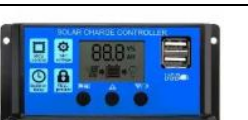 & $\begin{array}{l}\text { SCC (Solar Charge } \\
\text { Controller) }\end{array}$ & $\begin{array}{c}\text { Berfungsi untuk } \\
\text { mengontrol pengisian } \\
\text { Baterai dari Panel Surya }\end{array}$ \\
\hline & Pipa & $\begin{array}{c}\text { Untuk media pengaliran air } \\
\text { dari sumber ke } \\
\text { penampungan }\end{array}$ \\
\hline
\end{tabular}

Sumber: Hasil Penelitian tahun 2021 


\section{Hasil dan Pembahasan}

\section{A. Hasil Penelitian}

1. Pengujian dan Data Pengukuran

Pada pengukuran baterai terdapat perhitungan pengisian arus listrik dari panel terhadap baterai dan pemakaian daya terhadap Motor BLDC. Untuk data perhitungan dan pengukuran pada Motor BLDC dilakukan dengan kondisi berbeban dan tidak berbeban serta mengukur efisiensinya. Dalam pengukuran Mini Water Pump tidak dilakukan perhitungan efisiensi pompa dan hanya menghitung debit air yang dhasilkan. Perhitungan dilakukan selama 15 detik dan diukur dari pukul 07.00-17.00 selama 14 hari dan dihitung secara rata-rata per jam nya.

a. Pengujian dan Perhitungan Data Hasil Pengukuran Panel Surya Tanpa Beban dan Berbeban

Pada penelitian ini dilakukan pengukuran rata-rata per jam selama 14 hari percobaan yaitu mulai dari tanggal 10,11,12,13,14,18,19,20,23,25,26,27,29 April dan 01 Mei 2021.

Tabel 2

Data Pengukuran Panel Surya Tanpa Beban

\begin{tabular}{ccc}
\hline Jam & Daya (Watt) & $\begin{array}{c}\text { ingkat Pencahaayn } \\
\text { (Lux) }\end{array}$ \\
\hline 07.00 & 2,577811 & 7791,786 \\
\hline 08.00 & 4,786263 & 31194,64 \\
\hline 09.00 & 4,60674 & 33638,57 \\
\hline 10.00 & 7,77852 & 92772,15 \\
\hline 11.00 & 8,991073 & 150219,7 \\
\hline 12.00 & 8,971769 & 179755,7 \\
\hline 13.00 & 8,314226 & 166738 \\
\hline 14.00 & 6,846629 & 51746,69 \\
\hline 15.00 & 4,93117 & 33957,5 \\
\hline 16.00 & 2,875565 & 6750,5 \\
\hline 17.00 & 2,007324 & 4510,429 \\
\hline Average & 5,698826 & 69006,88 \\
\hline
\end{tabular}

Sumber: Hasil Penelitian Tahun 2021 
Tabel 3

Data Pengukuran Panel Surya Berbeban

\begin{tabular}{ccc}
\hline Jam & $\begin{array}{c}\text { Daya } \\
\text { (Watt) }\end{array}$ & $\begin{array}{c}\text { ingkat Pencahaayan } \\
\text { (Lux) }\end{array}$ \\
\hline 07.00 & 1,540696 & 7791,786 \\
\hline 08.00 & 3,395728 & 31194,64 \\
\hline 09.00 & 3,234587 & 33638,57 \\
\hline 10.00 & 5,946328 & 92772,15 \\
\hline 11.00 & 6,992937 & 150219,7 \\
\hline 12.00 & 6,97587 & 179755,7 \\
\hline 13.00 & 6,407936 & 166738 \\
\hline 14.00 & 5,059044 & 51746,69 \\
\hline 15.00 & 3,511846 & 33957,5 \\
\hline 16.00 & 1,775729 & 6750,5 \\
\hline 17.00 & 1,060428 & 4510,429 \\
\hline Average & 4,17283 & 69006,88 \\
\hline
\end{tabular}

Sumber: Hasil Penelitian Tahun 2021

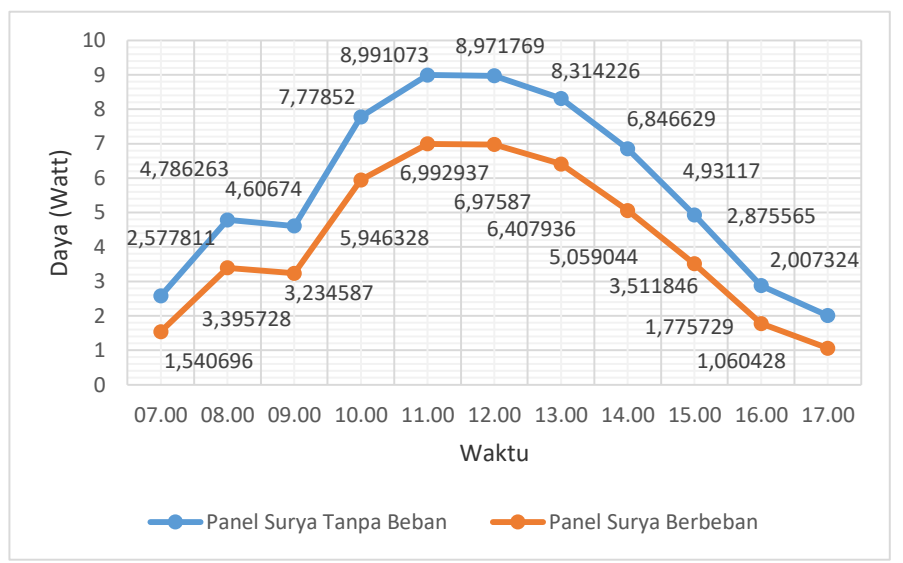

Gambar 1

Grafik Daya yang dihasilkan Panel Surya

b. Pengujian Kapasitas Baterai

Pada penelitian ini dilakukan pengukuran rata-rata per jam selama 14 hari percobaan yaitu mulai dari tanggal 10,11,12,13,14,18,19,20,23,25,26,27,29 April dan 01 Mei 2021 dan diukur selama 15 detik. 
Tabel 4

Data Pengukuran Kapasitas Baterai Berbeban Motor BLDC Ukuran 27 x 27 mm

\begin{tabular}{ccc}
\hline Jam & $\begin{array}{c}\text { Daya } \\
\text { BLC Motor } \\
\text { Berbeban } \\
\text { (Watt) }\end{array}$ & $\begin{array}{c}\text { Daya } \\
\text { BLDC Motor Tanpa } \\
\text { Beban } \\
\text { (Watt) }\end{array}$ \\
\hline 07.00 & 217,9008 & 16,812 \\
\hline 08.00 & 217,8792 & 16,788 \\
\hline 09.00 & 217,9438 & 16,86 \\
\hline 10.00 & 218,0191 & 16,944 \\
\hline 11.00 & 218,1052 & 17,04 \\
\hline 12.00 & 218,1805 & 17,124 \\
\hline 13.00 & 218,1052 & 17,04 \\
\hline 14.00 & 218,0084 & 16,932 \\
\hline 15.00 & 217,9438 & 16,86 \\
\hline 16.00 & 217,8362 & 16,74 \\
\hline 17.00 & 217,7501 & 16,584 \\
\hline Average & 217,9702 & 16,884 \\
\hline
\end{tabular}

Sumber: Hasil Penelitian Tahun 2021

Tabel 5

Data Pengukuran Kapasitas Baterai Berbeban Motor BLDC Ukuran 35 x 36 mm

\begin{tabular}{lll}
\hline Jam & $\begin{array}{c}\text { Daya } \\
\text { BLDC Motor } \\
\text { Berbeban } \\
\text { (Watt) }\end{array}$ & $\begin{array}{c}\text { Daya } \\
\text { BLD Motor } \\
\text { (Watt) }\end{array}$ \\
\hline 07.00 & 238,1508 & 29,412 \\
\hline 08.00 & 238,1292 & 29,388 \\
\hline 09.00 & 238,194 & 29,46 \\
\hline 10.00 & 238,2696 & 29,532 \\
\hline 11.00 & 238,356 & 29,64 \\
\hline 12.00 & 238,4316 & 29,724 \\
\hline 13.00 & 238,356 & 29,64 \\
\hline 14.00 & 238,2588 & 29,532 \\
\hline 15.00 & 238,1832 & 29,46 \\
\hline 16.00 & 238,086 & 29,34 \\
\hline 17.00 & 237,9996 & 29,244 \\
\hline Average & 238,2195 & 29,48836 \\
\hline
\end{tabular}

Sumber: Hasil Penelitian Tahun 2021 


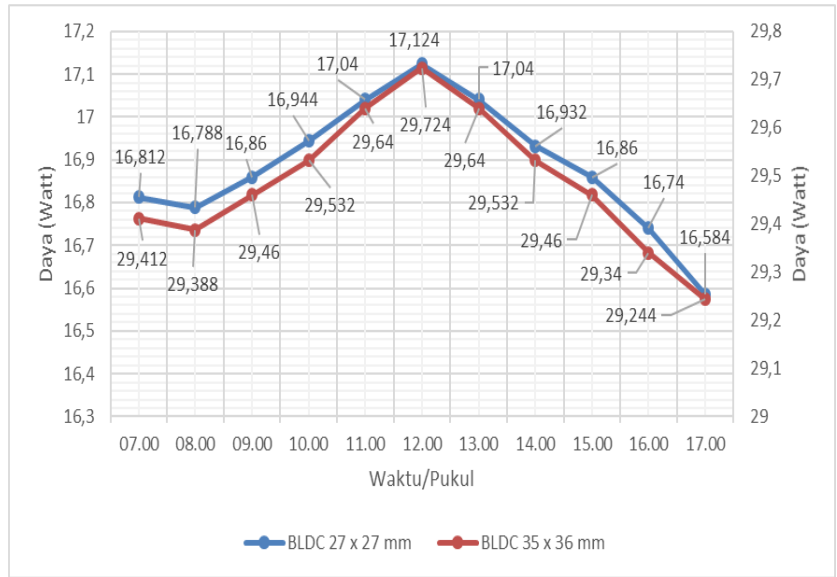

Gambar 2

Grafik Daya Yang Terpakai Oleh

Motor BLDC Tanpa Beban Terhadap Baterai

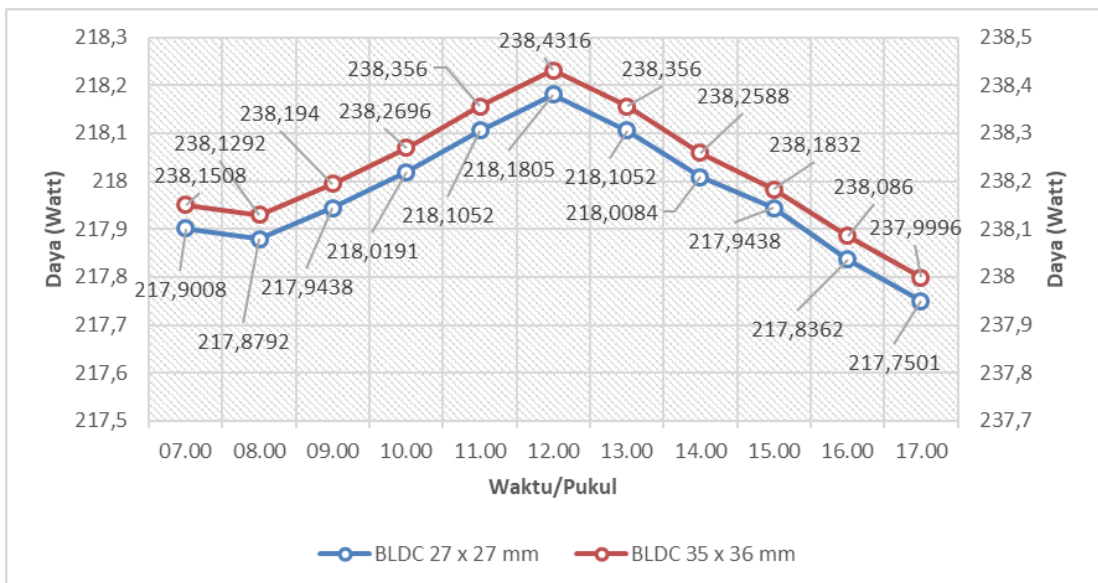

Gambar 3

Grafik Daya Yang Terpakai Oleh Motor BLDC Berbeban Terhadap Baterai

c. Pengujian Kapasitas Motor $B L D C$

Pada penelitian ini dilakukan pengukuran rata-rata per jam selama 14 hari percobaan yaitu mulai dari tanggal 10,11,12,13,14,18,19,20,23,25,26,27,29 April dan 01 Mei 2021 dan diukur selama 15 detik. 
Tabel 6

Data Pengukuran Kapasitas Motor BLDC Ukuran 27 x 27 mm

\begin{tabular}{ccc}
\hline Jam & $\begin{array}{c}\text { Daya } \\
\text { BLDC Motor } \\
\text { Berbeban } \\
\text { (Watt) }\end{array}$ & $\begin{array}{c}\text { Daya } \\
\text { 3otor Tanpa } \\
\text { Beban } \\
\text { (Watt) }\end{array}$ \\
\hline 07.00 & 178,021 & 14,532 \\
\hline 08.00 & 178,005 & 14,51 \\
\hline 09.00 & 178,05 & 14,576 \\
\hline 10.00 & 178,109 & 14,654 \\
\hline 11.00 & 178,173 & 14,743 \\
\hline 12.00 & 178,23 & 14,82 \\
\hline 13.00 & 178,173 & 14,743 \\
\hline 14.00 & 178,101 & 14,676 \\
\hline 15.00 & 178,053 & 14,576 \\
\hline 16.00 & 177,973 & 14,466 \\
\hline 17.00 & 177,908 & 14,377 \\
\hline Average & 178,0724 & 14,60664 \\
\hline
\end{tabular}

Sumber: Hasil Penelitian Tahun 2021

Tabel 7

Data Pengukuran Kapasitas Motor BLDC Ukuran 35 x 36 mm

\begin{tabular}{lcc}
\hline Jam & $\begin{array}{c}\text { Daya } \\
\text { BLDC Motor } \\
\text { Berbeban } \\
\text { (Watt) }\end{array}$ & $\begin{array}{c}\text { Daya } \\
\text { BLDC Motor } \\
\text { Tanpa Beban } \\
\text { (Watt) }\end{array}$ \\
\hline 07.00 & 206,707 & 25,803 \\
\hline 08.00 & 206,69 & 25,78 \\
\hline 09.00 & 206,698 & 25,849 \\
\hline 10.00 & 206,801 & 25,928 \\
\hline 11.00 & 206,87 & 26,019 \\
\hline 12.00 & 206,93 & 26,099 \\
\hline 13.00 & 206,87 & 26,019 \\
\hline 14.00 & 206,784 & 25,917 \\
\hline 15.00 & 206,741 & 25,849 \\
\hline 16.00 & 206,673 & 25,746 \\
\hline 17.00 & 206,587 & 25,644 \\
\hline Average & 206,7592 & 25,87755 \\
\hline Sumber: Hasil Penelitian Tahun 2021
\end{tabular}




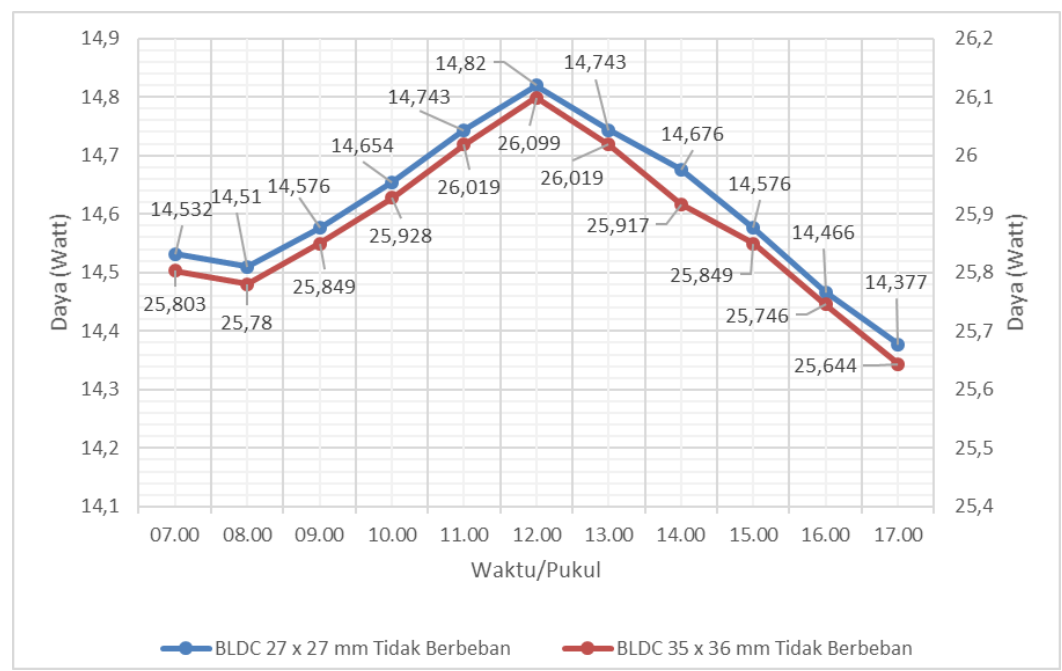

Gambar 4

Grafik Daya Output Motor BLDC Tanpa Beban

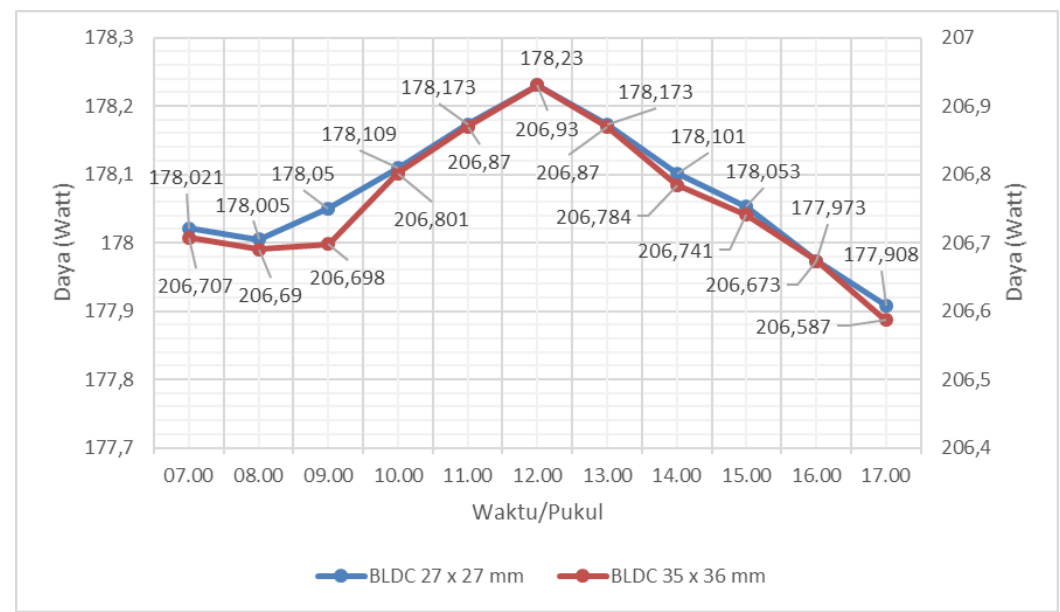

Gambar 5

Grafik Daya Output Motor BLDC Berbeban

\section{B. Pembahasan}

1. Lama Pengisian Panel Surya Terhadap Baterai

Rata-rata lama pengisian baterai sampai penuh selama 2 minggu yaitu : 0,31311 A. Lama pengisian baterai $(\mathrm{Jam})=$ Arus Baterai $(\mathrm{Ah}) /$ Arus Pengisian (A) $=7,2 /$ 0,31311 = 22,995 Jam. Pengisian baterai / aki yang dilakukan dimulai dari keadaan baterai kosong atau dibawah $20 \%$ dari kapsitas total baterai dan jika baterai masih cukup terisi maka lama pengisian akan berkurang bergantung dari jumlah kapasitas yang masih dimiliki baterai. 


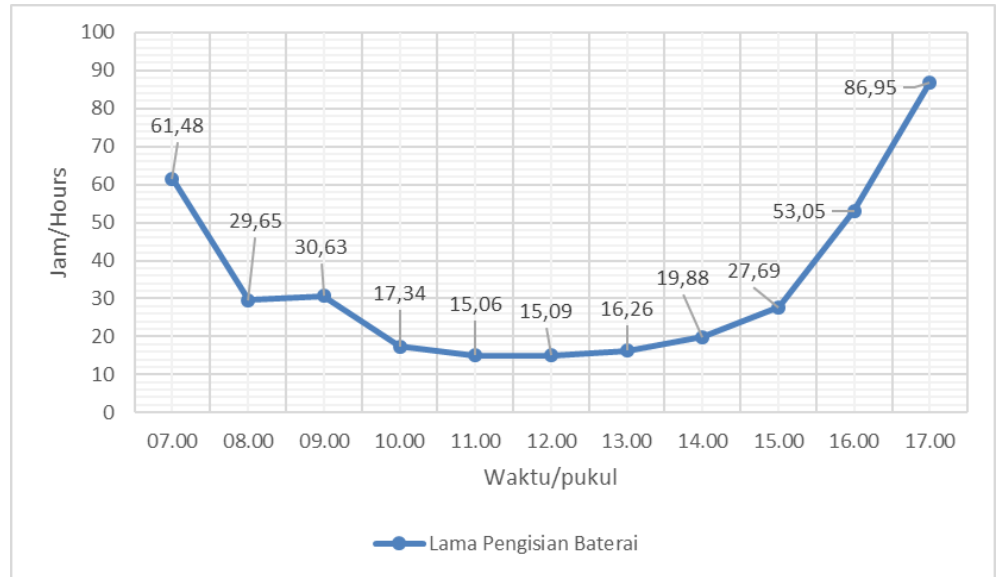

Gambar 6

Grafik Lama Pengisian Baterai Dari Panel Surya

2. Lama pemakaian Baterai

a. Pada Motor BLDC Ukuran 27 x 27 mm keadaan Tanpa beban

Arus rata-rata yang digunakan selama 2 minggu yaitu 1,407 A. Lama pemakaian baterai $(\mathrm{Jam})=($ Arus Baterai $(\mathrm{Ah}) /$ Arus Pemakaian (A)) Defisiensi Baterai $(20 \%)=(7,2 / 1,407)-20 \%=4,917$ Jam.

b. Pada Motor BLDC Ukuran 27 x 27 mm keadaan Berbeban

Arus rata-rata yang digunakan selama 2 minggu yaitu 20,25745 A. Lama pemakaian baterai (Jam) $=$ (Arus Baterai (Ah) / Arus Pemakaian (A)) Defisiensi Baterai $(20 \%)=(7,2 / 20,25745)-20 \%=9,324$ Menit

c. Pada Motor BLDC Ukuran 35 x $36 \mathrm{~mm}$ keadaan Tanpa beban

Arus rata-rata yang digunakan selama 2 minggu yaitu 2,457364 A. Lama pemakaian baterai $(\mathrm{Jam})=($ Arus Baterai $(\mathrm{Ah}) /$ Arus Pemakaian (A)) Defisiensi Baterai $(20 \%)=(7,2 / 2,457364)-20 \%=2,73 \mathrm{Jam}$

d. Pada Motor BLDC Ukuran 35 x 36 mm keadaan Berbeban

Arus rata-rata yang digunakan selama 2 minggu yaitu 22,05736 A. Lama pemakaian baterai $(\mathrm{Jam})=$ (Arus Baterai (Ah) / Arus Pemakaian (A)) Defisiensi Baterai $(20 \%)=(7,2 / 22,05736)-20 \%=7,585$ Menit

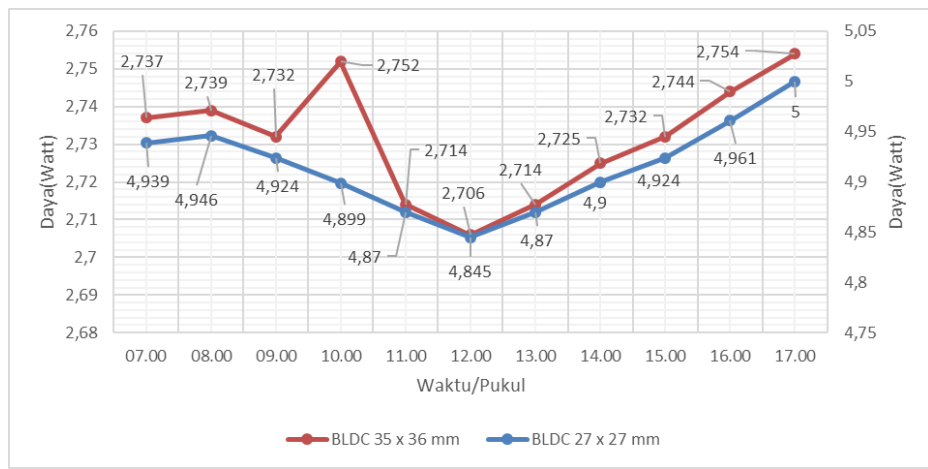

Gambar 7

Grafik Lama Pemakaian Baterai Terhadap Motor BLDC Tanpa Beban 


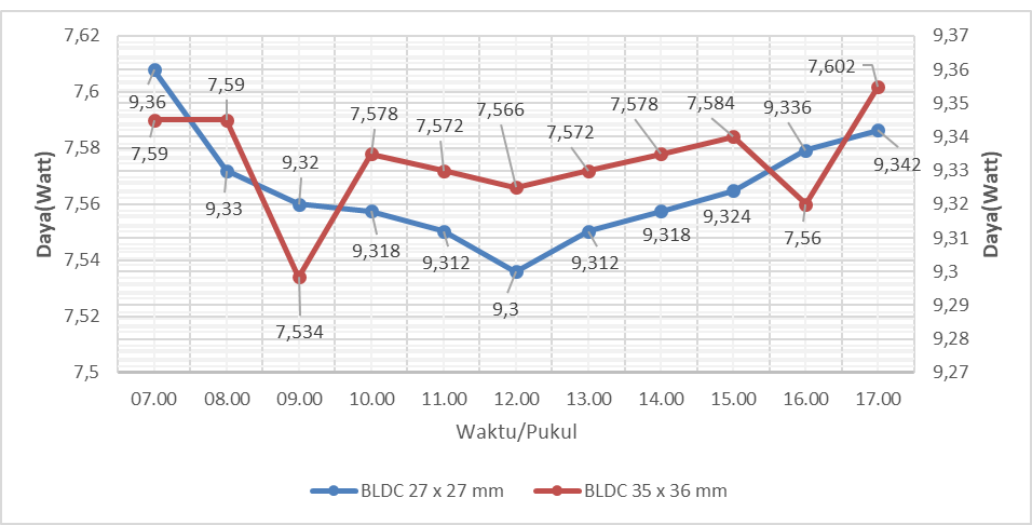

Gambar 8

\section{Grafik Lama Pemakaian Baterai Terhadap Motor BLDC Berbeban}

a. Efisiensi Motor BLDC Berbeban dan Tanpa Beban

Perhitungan Daya pada Motor $B L D C$ dilakukan dengan rumus:

$\mathrm{P}_{\text {out }}=\sqrt{ } 3 \times \mathrm{V} \times \mathrm{I} \times \cos \phi$, di mana untuk faktor daya nya yaitu 0,8 .

b. Perhitungan Pada Motor BLDC Ukuran 27 x $27 \mathrm{~mm}$

Pada Kondisi Tanpa Beban: Pengukuran Motor $B L D C$ dihitung efisiensi dari Motor tersebut di mana rumusnya yaitu: Efisiensi $=($ Pout $/$ Pin $) \times 100 \%$. Daya Input rata-rata didapatkan pada daya yang terpakai pada baterai yaitu sebesar $P_{\text {in }}$ $=16,884$ Watt Daya Output rata-rata $\left(\mathrm{P}_{\text {out }}\right)=14,60664$ Watt Efisiensi $=(14,60664$ / 16,884$) \times 100 \%=86,51 \%$

Pada Kondisi Berbeban : Pengukuran Motor $B L D C$ dihitung efisiensi dari Motor tersebut di mana rumusnya yaitu: Efisiensi $=($ Pout $/$ Pin $) \times 100 \%$ Daya Input rata-rata didapatkan pada daya yang terpakai pada baterai yaitu sebesar $P_{\text {in }}$ $=217,9702$ Watt Daya Output rata-rata $\left(\mathrm{P}_{\text {out }}\right)=178,0724$ Watt Efisiensi $=$ $(178,0724 / 217,9702) \times 100 \%=81,69 \%$

c. Perhitungan Pada Motor BLDC Ukuran 35 x $36 \mathrm{~mm}$

Pada Kondisi Tanpa Beban: Pengukuran Motor $B L D C$ dihitung efisiensi dari Motor tersebut di mana rumusnya yaitu: Efisiensi $=($ Pout $/$ Pin $) \times 100 \%$ Daya Input rata-rata didapatkan pada daya yang terpakai pada baterai yaitu sebesar $P_{\text {in }}$ $=29,48836$ Watt Daya Output rata-rata $\left(\mathrm{P}_{\text {out }}\right)=25,87755$ Watt Efisiensi $=$ $(25,87755 / 29,48836) \times 100 \%=87,75 \%$

Pada Kondisi Berbeban: Pengukuran Motor BLDC dihitung efisiensi dari Motor tersebut di mana rumusnya yaitu: Efisiensi $=($ Pout $/$ Pin $) \times 100 \%$ Daya Input rata-rata didapatkan pada daya yang terpakai pada baterai yaitu sebesar $\mathrm{P}_{\text {in }}$ $=238,219$ Watt Daya Output rata-rata $\left(\mathrm{P}_{\text {out }}\right)=206,7592$ Watt Efisiensi $=$ $(206,7592 / 238,219) \times 100 \%=86,79 \%$.

d. Debit Air yang dihasilkan

1) Perhitungan Aliran Air Pada Motor BLDC Ukuran $27 \times 27$ mm

Rata-rata volume dan debit yang dihasilkan dari mini water pump yaitu: 
Volume $=8,3988$ Liter

Debit $(\mathrm{Q})=\mathrm{V} / \mathrm{t}=(8,3988$ Liter $) /(15)$

Debit $(\mathrm{Q})=0,55992 \mathrm{~L} / \mathrm{s}$

2) Perhitungan Aliran Air Pada Motor BLDC Ukuran 35 x 36 mm

Rata-rata volume dan debit yang dihasilkan dari mini water pump yaitu:

Volume $=8,9532$ Liter

Debit $(\mathrm{Q})=\mathrm{V} / \mathrm{t}=(8,9532) /(15)$

Debit $(\mathrm{Q})=0,59688 \mathrm{~L} / \mathrm{s}$

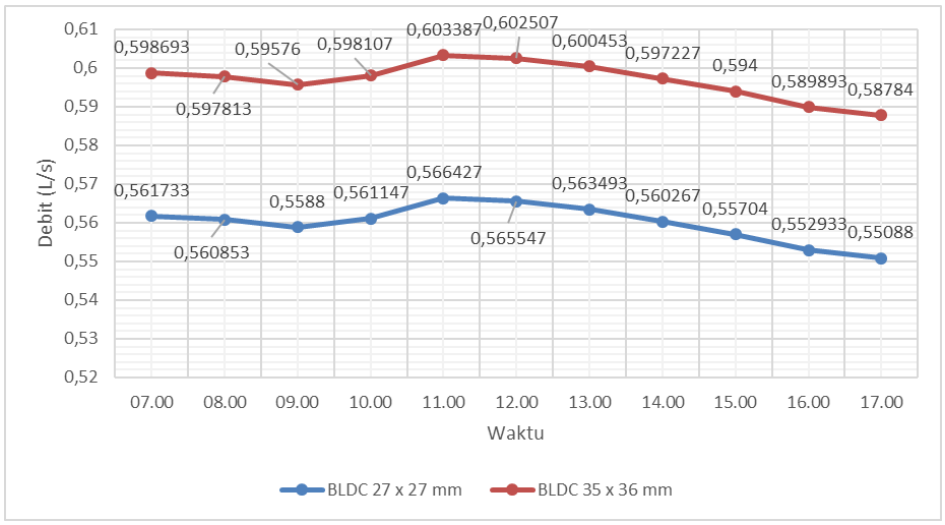

\section{Gambar 9}

Grafik Debit Yang Dihasilkan Mini Water Pump BLDC Motor

\section{Analisa Hasil Penelitian}

Pengukuran pada panel surya yang terlihat pada Gambar 1 terlihat bahwa daya yang dihasilkan pada kondisi tanpa beban lebih besar dibandingkan dengan kondisi berbeban dikarenakan pada kondisi berbeban terdapat nilai hambatan yang mengurangi nilai dari tegangan dan arusnya. Kondisi cuaca sangat mempengaruhi pada daya yang didapatkan pada panel surya. Daya tertinggi yang didapat pada pukul 12.00 yaitu 8,971769 Watt kondisi tanpa beban dan 6,97587 Watt pada kondisi berbeban dan total rata-rata daya yang dihasilkan oleh panel surya selama 2 minggu yaitu 5,698826 Watt kondisi tanpa beban dan 4,17283 Watt kondisi berbeban. Waktu pengisian yang dapat dilakukan panel surya pada Gambar 6 untuk mengisi kapasitas baterai sampai penuh yaitu tercepat pada pukul 12.00 dengan waktu 15,9 jam dan terlama pada pukul 17.00 dengan waktu 86,95 jam. Rata-rata waktu yang dibutuhkan dalam pengisian baterai selama 2 minggu yaitu 22,995 jam. Lama pengisian untuk baterai tergantung dari arus yang dapat dihasilkan oleh panel surya tersebut. Nilai dari lama pengisian arus tersebut ketika baterai sudah mencapai titik kosong atau tidak dapat lagi memberikan daya kepada beban.

Pengukuran pada baterai yang terlihat pada Gambar 2 yang digunakan untuk mensuplai daya pada Motor BLDC tanpa beban. Nilai daya antara $B L D C$ ukuran $27 \mathrm{x}$ $27 \mathrm{~mm}$ dengan $B L D C 35 \times 36 \mathrm{~mm}$ memiliki selisih yang cukup jauh di mana daya yang digunakan untuk menggerakan $B L D C 35 \times 36 \mathrm{~mm}$ lebih tinggi dibandingkan $B L D C$ ukuran $27 \times 27 \mathrm{~mm}$. Di mana rata-rata daya yang dipakai selama 2 minggu 
yaiitu 16,884 Watt untuk $B L D C$ ukuran 27 x $27 \mathrm{~mm}$ dan 29,48836 Watt untuk $B L D C$ ukuran 35 x $36 \mathrm{~mm}$. Pengukuran untuk berbeban terlihat pada Gambar 3 di mana nilai daya yang digunakan rata-rata dalam 2 minggu yaitu 217,9702 Watt untuk $B L D C$ ukuran $27 \times 27 \mathrm{~mm}$ dan 238,2195 Watt untuk $B L D C$ ukuran 35 x $36 \mathrm{~mm}$.

Untuk lama pemakaian baterai yang dapat digunakan oleh Motor BLDC terlihat pada Gambar 7 dengan kondisi tanpa beban rata-rata selama 2 minggu yaitu 4,917 Jam untuk $B L D C$ ukuran 27 x 27 mm dan 2,73 Jam untuk $B L D C$ ukuran 35 x 36 mm. Pada kondisi berbeban terlihat pada Gambar 8 lama pemakaian baterai yang dapat digunakan untuk beroperasi rata-rata selama 2 minggu yaitu 9,324 menit untuk $B L D C$ ukuran $27 \times 27 \mathrm{~mm}$ dan 7,585 menit untuk $B L D C$ ukuran 35 x $36 \mathrm{~mm}$. Pemakaian daya akan berbanding lurus dengan lama baterai dapat dipakai, di mana semakin tinggi daya yang digunakan maka akan semakin cepat waktu baterai akan habis. Disebabkan dalam pemakaian baterai tidak dilakukan secara terus menerus dan sambil di isi arus listrik dari panel surya maka ketahanan pada baterai yang digunakan ini cukup untuk dilakukan dalam berkali-kali pengukuran.

Pada pengukuran Motor BLDC dengan kondisi tanpa beban terlihat pada Gambar 4 di mana daya output yang dihasilkan rata-rata selama 2 minggu yaitu 14,60664 Watt untuk BLDC ukuran $27 \times 27 \mathrm{~mm}$ dan 22,69518 Watt untuk $B L D C$ ukuran 35 x $36 \mathrm{~mm}$. Pada kondisi berbeban terlihat pada Gambar 5 di mana daya output yang dihasilkan rata-rata selama 2 minggu yaitu 178,0724 Watt untuk $B L D C$ ukuran 27 x $27 \mathrm{~mm}$ dan 206,7592 Watt untuk $B L D C$ ukuran 35 x $36 \mathrm{~mm}$. Nilai daya output yang dihasilkan akan berbanding lurus dengan ukuran pada Motor BLDC tersebut dikarenakan panjang lilitan yang lebih besar serta nilai torsi yang semakin besar juga akan membutuhkan daya yang besar. Pada Motor BLDC nilai tegangan tidak berubah dan hanya nilai dari arus yang berubah sedikit namun tidak signifikan dikarenakan menggunakan baterai di mana daya yang dihasilkan baterai cukup stabil. Untuk efisiensi yang didapatkan pada Motor BLDC dengan kondisi tanpa beban yaitu $86,51 \%$ untuk $B L D C$ ukuran 27 × 27 mm dan 87,75\% untuk $B L D C$ ukuran 35 x 36 mm. Untuk kondisi berbeban efisiensi yang didapat yaitu 81,69\% untuk BLDC ukuran 27 x $27 \mathrm{~mm}$ dan 86,79\% untuk BLDC ukuran 35 x $36 \mathrm{~mm}$.

Nilai efisiensi yang didapatkan pada pengukuran Motor BLDC lebih tinggi nilai efisiensi yang didapatkan ketika tidak diberikan beban dikarenakan rugi-rugi yang terjadi hanya pada Motor BLDC dan untuk efisiensi ketika diberikan beban akan mengecil dikarenakan terdapat rugi-rugi tambahan seperti rugi gesekan pipa. Nilai efisiensi pada $B L D C$ ukuran 35 x $36 \mathrm{~mm}$ lebih besar ketika diberikan beban dikarenakan torsi yang dihasilkan lebih besar dari pada $B L D C$ ukuran 27 x $27 \mathrm{~mm}$.

Untuk pengukuran debit air yang didapatkan terlihat pada Gambar 9 dimana rata-rata debit yang dihasilkan selama 2 minggu yaitu $0,55992 \mathrm{~L} / \mathrm{s}$ untuk $B L D C$ ukuran 27 x $27 \mathrm{~mm}$ dan 0,59688 L/s untuk $B L D C$ ukuran 35 x $36 \mathrm{~mm}$. Debit air yang dihasilkan akan sebanding dengan nilai daya dan torsi yang dihasilkan dari penggerak Mini Water Pump tersebut yaitu Motor BLDC. 


\section{Kesimpulan}

Berdasarkan penelitian yang telah dilakukan dalam analisa kapasitas Outrunner Motor BLDC sebagai penggerak Mini Water Pump, dapat disimpulkan bahwa nilai efisiensi Motor BLDC dengan kondisi berbeban lebih kecil dibandingkan dengan kondisi tanpa beban disebabkan pada kondisi berbeban rugi-rugi pada Motor BLDC akan bertambah karena memutar impeller yang didalamnya terdapat rugi gesekan. Sedangkan pada daya output Motor BLDC lebih besar pada keadaan berbeban dibandingkan pada saat tidak berbeban dikarenakan ketika berbeban Motor BLDC akan membutuhkan torsi lebih banyak untuk memutar impeller yang terkena aliran air tersebut. Pemakaian daya pada baterai untuk memutar Motor BLDC lebih besar pada ukuran 35 x $36 \mathrm{~mm}$ dikarenakan semakin besar ukuran Motor BLDC maka akan semakin panjang lilitan didalamnya. Untuk lama pemakaian baterai akan sebanding dengan nilai daya yang dibutuhkan Motor BLDC di mana semakin besar daya yang dibutuhkan maka akan semakin cepat waktu pemakaian habis baterai. Pengisian daya pada baterai akan sebanding dengan nilai daya yang dihasilkan pada panel surya, di mana jika semakin besar nilai arus pada panel surya maka akan semakin cepat waktu pengisian terhadap baterai. Debit air yang dihasilkan pada Mini Water Pump lebih besar pada Motor BLDC ukuran 35 x $36 \mathrm{~mm}$ yaitu 0,59688 L/s dan 0,55992 L/s untuk ukuran Motor BLDC $27 \times 27 \mathrm{~mm}$. Jadi semakin besar ukuran motor akan semakin cepat perputarannya serta semakin cepat dalam pengisian air karena beban yang di gunakan akan berkurang. 


\section{BIBLIOGRAFI}

Ainurrohmah, Arista, Muhammad Rivai, And Tasripan Tasripan. 2019. "Kontrol Laju Alir Pompa Air Berpenggerak Brushless DC Motor.” Jurnal Teknik ITS 7(2). Doi: 10.12962/J23373539.V7i2.31133. Google Scholar

Akbar, Danu, And Slamet Riyadi. 2019. "Pengaturan Kecepatan Pada Motor Brushless Dc (Bldc) Menggunakan Pwm (Pulse Width Modulation)." 255-62. Doi: 10.5614/Sniko.2018.30.Google Scholar

Antono, Djodi. 2012. "Motor DC Brushless Tiga Fasa-Satu Kutub.” Orbith 8(1):3237.Google Scholar

Candra, Riki. 2018. "Perancangan Pompa Sentrifugal Dan Diameter Luar Impeller Untuk Kebutuhan Air Kapasitas 60 Lpm Di Gedung F Dan D Universitas Muhammadiyah Tangerang.” Jurnal Teknik 7(1):15-25. Doi: 10.31000/Jt.V7i1.946. Google Scholar

Chandra Wibowo, Yunus, And Slamet Riyadi. 2019. "Analisa Pembebanan Pada Motor Brushless Dc (Bldc).” 277-82. Doi: 10.5614/Sniko.2018.33.Google Scholar

Jatmiko, Jatmiko, Abdul Basith, Agus Ulinuha, Muhammad Afan Muhlasin, And Ibnu Shokibul Khak. 2018. "Analisis Peroforma Dan Konsumsi Daya Motor Bldc 350 W Pada Prototipe Mobil Listrik Ababil.” Emitor: Jurnal Teknik Elektro 18(2):1417. Doi: 10.23917/Emitor.V18i2.6348.Google Scholar

Joon, Sung Park, Bon Gwan Gu, Jin Hong Kim, Jun Hyuk Choi, And In Soung Jung. 2012. "Development Of BLDC Motor Drive For Automotive Applications." In Electrical Systems For Aircraft, Railway And Ship Propulsion, ESARS.Google Scholar

Julisman, Andi, Ira Devi Sara, And Ramdhan Halid Siregar. 2017. "Prototipe Pemanfaatan Panel Surya Sebagai Sumber Energi Pada Sistem Otomasi Stadion Bola." Jurnal Komputer, Informasi Teknologi, Dan Elektro 2(1):35-42.Google Scholar

Krishna, M. Hari, And S. Manmadharao. 2018. "Grid Integrated Solar Irrigation System By Using BLDC Motor Pump Set.” Proceedings Of The International Conference On Inventive Research In Computing Applications, ICIRCA 2018 (Icirca):126164. Doi: 10.1109/ICIRCA.2018.8597257.Google Scholar

Kumar, Rajan, Bhim Singh, Ambrish Chandra, And Kamal Al-Haddad. 2015. "Solar 
PV Array Fed Water Pumping Using BLDC Motor Drive With Boost-Buck Converter.” 2015 IEEE Energy Conversion Congress And Exposition, ECCE 2015 5741-48. Doi: 10.1109/ECCE.2015.7310466.Google Scholar

Purwoto, Bambang Hari. 2018. "Efisiensi Penggunaan Panel Surya Sebagai Sumber Energi Alternatif." Emitor: Jurnal Teknik Elektro 18(01):10-14. Doi: 10.23917/Emitor.V18i01.6251.Google Scholar

Suryaputra, Andre, Wahmisari Priharti, M. Sc, D. Ph, Ig Prasetya, And Dwi Wibawa. 2019. "Desain Dan Implementasi Mppt Solar Charge Controller Berbasis Arduino Design And Implementation Of Mppt Solar Charge Controller Based On Arduino." 6(2):2617-22.Google Scholar

Sutedjo, Ony Asrarul Qudsi, Suhariningsih, And Diah Septi Yanaratri. 2017. "Desain Dan Implementasi Six-Step Comutation Pada Sistem Kontrol Motor Bldc 1 , 5 Kw." 3:261-73.Google Scholar

Udin, Mambak, Bambang Sri Kaloko, And Triwahju Hardianto. 2017. "Peramalan Kapasitas Baterai Lead Acid Pada Mobil Listrik Berbasis Levenberg Marquardt Neural Network." Berkala Sainstek 5(2):112. Doi: 10.19184/Bst.V5i2.5703.Google Scholar

Widaningrum, Lidya, Budi Setiyono, And Munawar Agus Riyadi. 2017. "Perancangan Kontroler Jaringan Syaraf Tiruan B-Spline Berbasis Mikrokontroler Atmega16 Sebagai Kendali Kecepatan Motor Brushless Dc (Bldc).” Transient 6(3):373. Doi: 10.14710/Transient.6.3.373-379.Google scholar

\section{Copyright holder :}

Sariman, Niko Andrean (2021)

First publication right:

Jurnal Syntax Admiration

This article is licensed under:

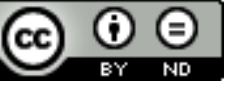

